\title{
Water Quality and the Effects of Changes in Phosphorus Loading to Muskellunge Lake, Vilas County, Wisconsin
}
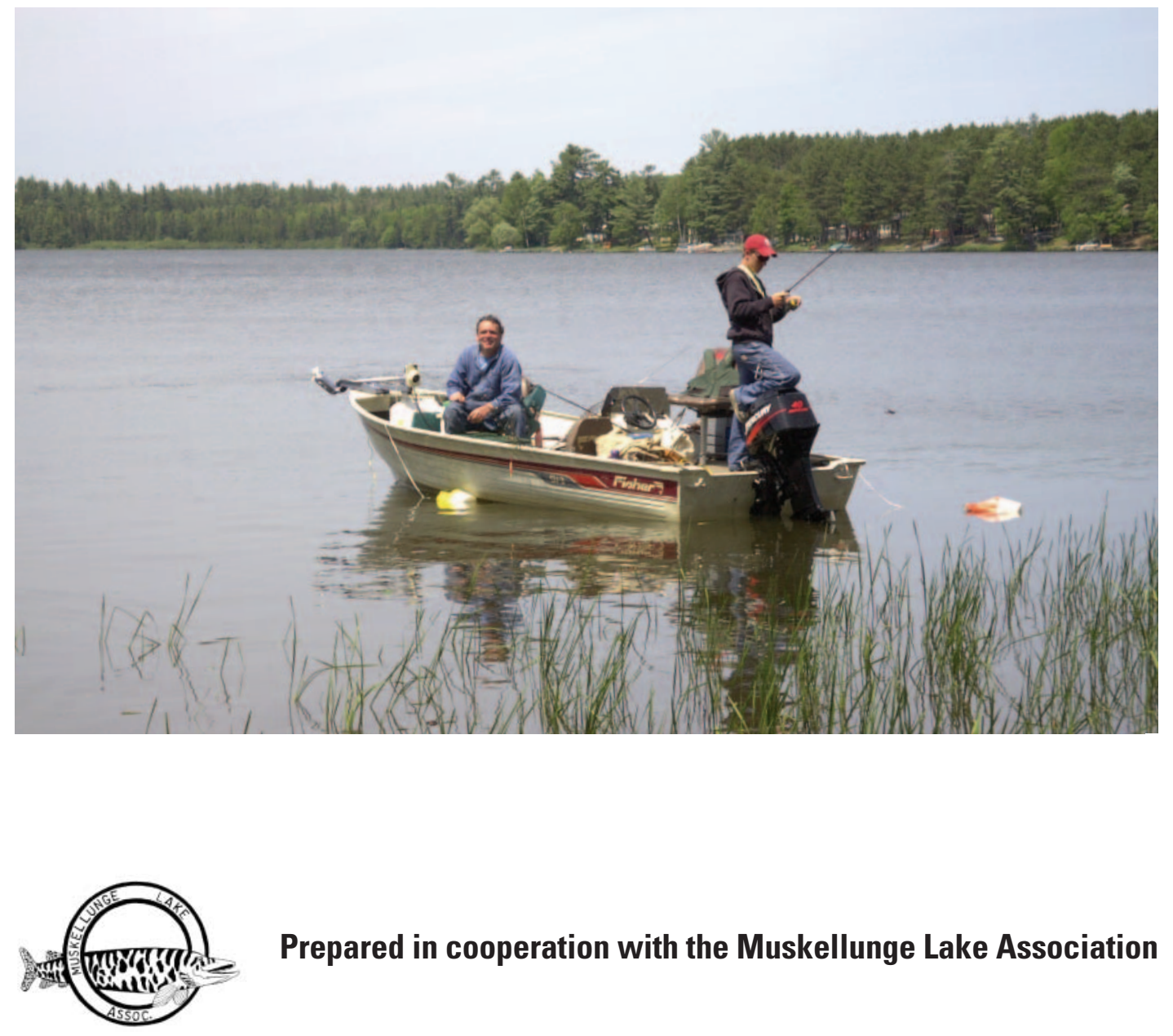

Prepared in cooperation with the Muskellunge Lake Association

Water-Resources Investigations Report 03-4011

U.S. Department of the Interior

U.S. Geological Survey 


\section{Water Quality and the Effects of Changes in Phosphorus Loading to Muskellunge Lake, Vilas County, Wisconsin}

By Dale M. Robertson, William J. Rose, and David A. Saad

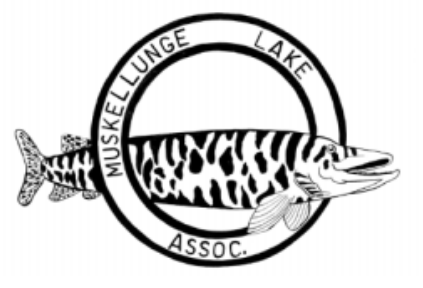

Water-Resources Investigations Report 03-4011

Middleton, Wisconsin: 2003 


\title{
U.S. Department of the Interior \\ Gale A. Norton, Secretary
}

\section{U.S. Geological Survey Charles G. Groat, Director}

\author{
For additional information about this report, write to: \\ District Chief \\ U.S. Geological Survey \\ 8505 Research Way \\ Middleton, WI 53562-3586 \\ World Wide Web: http://wi.water.usgs.gov/ \\ For sale by U.S. Geological Survey, Information Services \\ Box 25286, Denver Federal Center \\ Denver, CO 80225 \\ For more information about the USGS and its products: \\ Telephone: 1-888-ASK-USGS \\ World Wide Web: http://www.usgs.gov/
}

Any use of trade, product, or firm names in this publication is for descriptive purposes only and does not imply endorsement by the U.S. Government.

Although this report is in the public domain, it may contain copyrighted materials that are noted in the text. Permission to reproduce those items must be secured from the individual copyright owners. 


\section{Contents}

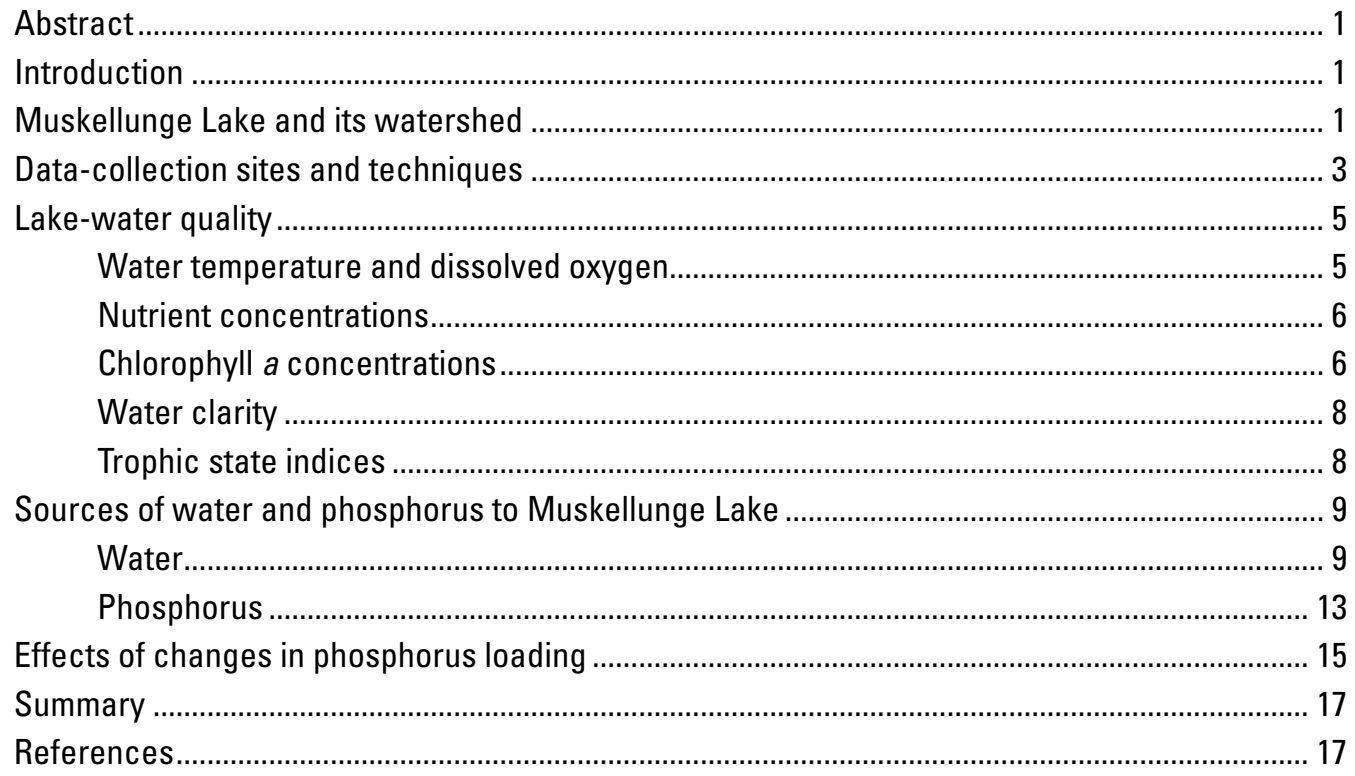

\section{Figures}

1-2. Maps showing:

1. Muskellunge Lake, Wisconsin, and surrounding area, with surface-water and ground-water contributing areas identified

2. Data-collection sites for Muskellunge Lake, Wisconsin, and watershed boundaries

3-6. Graphs showing:

3. Water temperature and dissolved oxygen distributions near the deep hole in Muskellunge Lake, Wisconsin, on March 21, 2001 (with aeration) and March 12, 2002 (without aeration)

4. Dissolved oxygen distribution in several locations in Muskellunge Lake, Wisconsin, on March 21, 2001, with aeration system in operation

5. Concentrations of total phosphorus and chlorophyll $a$, and Secchi depths near the deep hole in Muskellunge Lake, Wisconsin. 7

6. Trophic state indices based on surface concentrations of total phosphorus and chlorophyll $a$, and Secchi depths collected near the deep hole in Muskellunge Lake, Wisconsin 8

7. Schematic of the hydrologic cycle of Muskellunge Lake, Wisconsin.............................. 9

8. Daily average lake stages (measured and calculated) of Muskellunge Lake, Wisconsin

9. Ground-water-flow paths to Muskellunge Lake, Wisconsin ............................................ 12

10-11. Graphs showing:

10. Water budget for Muskellunge Lake, Wisconsin, November 1, 2000 to October 31, 2001

11. Phosphorus budget for Muskellunge Lake, Wisconsin, November 1, 2000 to October 31, 2001 


\section{Tables}

1. Monthly water budget for Muskellunge Lake, Wisconsin, November 1, 2000 to October 31, 2001.

2. Monthly phosphorus budget for Muskellunge Lake, Wisconsin, November 1, 2000 to October 31, 2001.

3. Estimated phosphorus concentrations in Muskellunge Lake from various phosphorus-loading models contained in the Wisconsin Lakes Modeling Suite 


\title{
Conversion Factors and Abbreviated Water-Quality Units
}

\begin{tabular}{rcl}
\hline Multiply & By & To Obtain \\
inch (in.) & 25.4 & millimeter \\
inch per day(in/d) & 25.4 & millimeter per day \\
inch per year (in/yr) & 25.4 & millimeter per year \\
foot (ft) & 3.2808 & meter \\
foot per day (ft/d) & 3.2808 & meter per day \\
mile (mi) & 1.6093 & kilometer \\
acre & .004047 & kilometer squared \\
acres-foot (acre-ft) & 1233.4818 & cubic meter \\
pound (lb) & .4536 & kilogram \\
cubic foot per second (ft $/ \mathrm{s})$ & .02583 & cubic meter per second \\
Temperature, in degrees Celsius $\left({ }^{\circ} \mathrm{C}\right)$ can be converted to degrees Fahrenheit $\left({ }^{\circ} \mathrm{F}\right)$ \\
by use of the following equation: \\
\multicolumn{3}{c}{$\mathrm{F}=\left[1.8 \mathrm{x}{ }^{\circ} \mathrm{C}\right]+32}$. \\
\hline
\end{tabular}

Water year: Water year is defined as the period beginning October 1 and ending September 30, designated by the calendar year in which it ends.

\begin{abstract}
Abbreviated water-quality units used in this report: Chemical concentrations and water temperature are given in metric units. Chemical concentration is given in milligrams per liter $(\mathrm{mg} / \mathrm{L})$ or micrograms per liter $(\mu \mathrm{g} / \mathrm{L})$. Milligrams per liter is a unit expressing the concentration of chemical constituents in solution as weight (milligrams) of solute per unit volume (liter) of water. One thousand micrograms per liter is equivalent to one milligram per liter. For concentrations less than $7,000 \mathrm{mg} / \mathrm{L}$, the numerical value is the same as for concentrations in parts per million.
\end{abstract}




\section{Acknowledgments}

\section{Technical Reviewers}

Herbert S. Garn, Supervisory Hydrologist, U.S. Geological Survey, Middleton, Wis.

Richard Heleniak, Muskellunge Lake Committee, Eagle River, Wis.

Art Horton, Muskellunge Lake Committee, Eagle River, Wis.

Jennifer K. Wudi, Water Resources Specialist-Lake Management Coordinator, Wisconsin Department of Natural Resources, Rhinelander, Wis.

\section{Project Coordinators}

Tom Fountaine, Muskellunge Lake Committee, Eagle River, Wis.

Chester Moore, Muskellunge Lake Committee, Eagle River, Wis.

\section{Editorial and Graphics}

Michael Eberle, Technical Publications Editor, U.S. Geological Survey, Columbus, Ohio Michelle M. Greenwood, Cartographer, U.S. Geological Survey, Middleton, Wis.

Leah N. Hout, Editor, U.S. Geological Survey, Columbus, Ohio Susan Z. Jones, Editorial Assistant, U.S. Geological Survey, Middleton, Wis. Jennifer L. Bruce, Publications Assistant, U.S. Geological Survey, Middleton, Wis. Chester Zenone, Hydrologist (Retired), U.S. Geological Survery, Reston, Va.

\section{Data Collection}

Stephanie M. Berg, Student Trainee, U.S. Geological Survey, Middleton, Wis. Jeffrey J. Hannig, Hydrological Technician, U.S. Geological Survey, Merrill, Wis. Richard Heleniak, Muskellunge Lake Committee, Eagle River, Wis.

Daniel L. Olson, Hydrological Technician, U.S. Geological Survey, Middleton, Wis.

Elissa D. Roerish, Hydrological Technician, U.S. Geological Survey, Middleton, Wis.

\section{Approving Official}

Dorothy H. Tepper, Reports Improvement Advisor, U.S. Geological Survey, Reston, Va. 


\title{
Water Quality and the Effects of Changes in Phosphorus Loading to Muskellunge Lake, Vilas County, Wisconsin
}

\author{
By Dale M. Robertson, William J. Rose, and David A. Saad
}

\begin{abstract}
Muskellunge Lake is a productive, eutrophic lake because of high nutrient loading. Historical data indicate that water quality has only slightly degraded since the early 1970s, possibly because of phosphorus input from effluent from septic systems. A detailed phosphorus budget for the lake indicated that most of the phosphorus comes from natural sources-ground water and surface water flowing through relatively undeveloped areas surrounding the lake. Modeling results indicated that the natural input of phosphorus was sufficient to maintain the lake's eutrophic condition. Analysis of sediment cores confirmed that only small changes in nutrient and algal concentrations have occurred over the past 100 years; however, the analysis indicated that the macrophyte community has increased over this time period. The aeration system, installed to alleviate winter anoxia, maintains aerobic conditions throughout the main bays of the lake.
\end{abstract}

\section{Introduction}

Muskellunge Lake is in Vilas County, Wisconsin, about 6 mi west of Eagle River (fig. 1). In the early 1960s, the lake was described as being moderately productive (relatively high concentrations of nutrients and algae, and relatively high fish populations), with clear water of low transparency, and bottom material consisting predominantly of muck (Black and others, 1963). In many shallow, productive lakes like Muskellunge Lake, dissolved oxygen concentrations throughout the lake are near saturation when the lake freezes; however, as winter progresses, oxygen is consumed. If ice and snow cover is present for a sufficient period of time, dissolved oxygen throughout the lake can drop below critical concentrations (usually considered below $2 \mathrm{mg} / \mathrm{L}$ ) and cause fish kills (this is often referred to as a "winterkill"). Winterkill occasionally occurs in Muskellunge Lake. In the interest of protecting and improving water quality and the lake's fishery, the Muskellunge Lake Association was established in 1991. Beginning in 1992, the Association began collecting water-quality data as part of the Wisconsin Department of Natural Resource's (WDNR) Self-Help Citizen Lake Monitoring Program (Wisconsin Department of Natural Resources, 2002). To prevent winterkills from occurring in Muskellunge Lake, the Association, with partial support from the Musky Clubs Alliance of Wisconsin, installed an aeration system in the fall of 1995 (the location of the aerator is shown in fig. 1) and operated it every winter except the winter of 2001-02.

Continuing concern over degrading water quality in the lake led to a cooperative effort with the U.S. Geological Survey (USGS) beginning in 2000 to evaluate the water quality of the lake in terms of long-term trends, to evaluate the effectiveness of the aerator in maintaining adequate dissolved oxygen concentration throughout the lake, to quantify the sources of phosphorus to the lake, and to determine how the lake would respond to changes in phosphorus loading. This report presents the results of this effort.

\section{Muskellunge Lake and its Watershed}

Muskellunge Lake has a surface area of 272 acres and volume of 2,520 acre-ft. The lake has a maximum depth of $19 \mathrm{ft}$ and mean depth of $9.3 \mathrm{ft}$. Most of the water enters the lake through ground water and precipitation; however, a small tributary on the southeast side of the lake and overland flow episodically discharge water to the lake. Outflow from the lake is to Muskellunge Creek, which leaves the west side of the lake and flows to Little St. Germain Lake, about 3 mi downstream. 


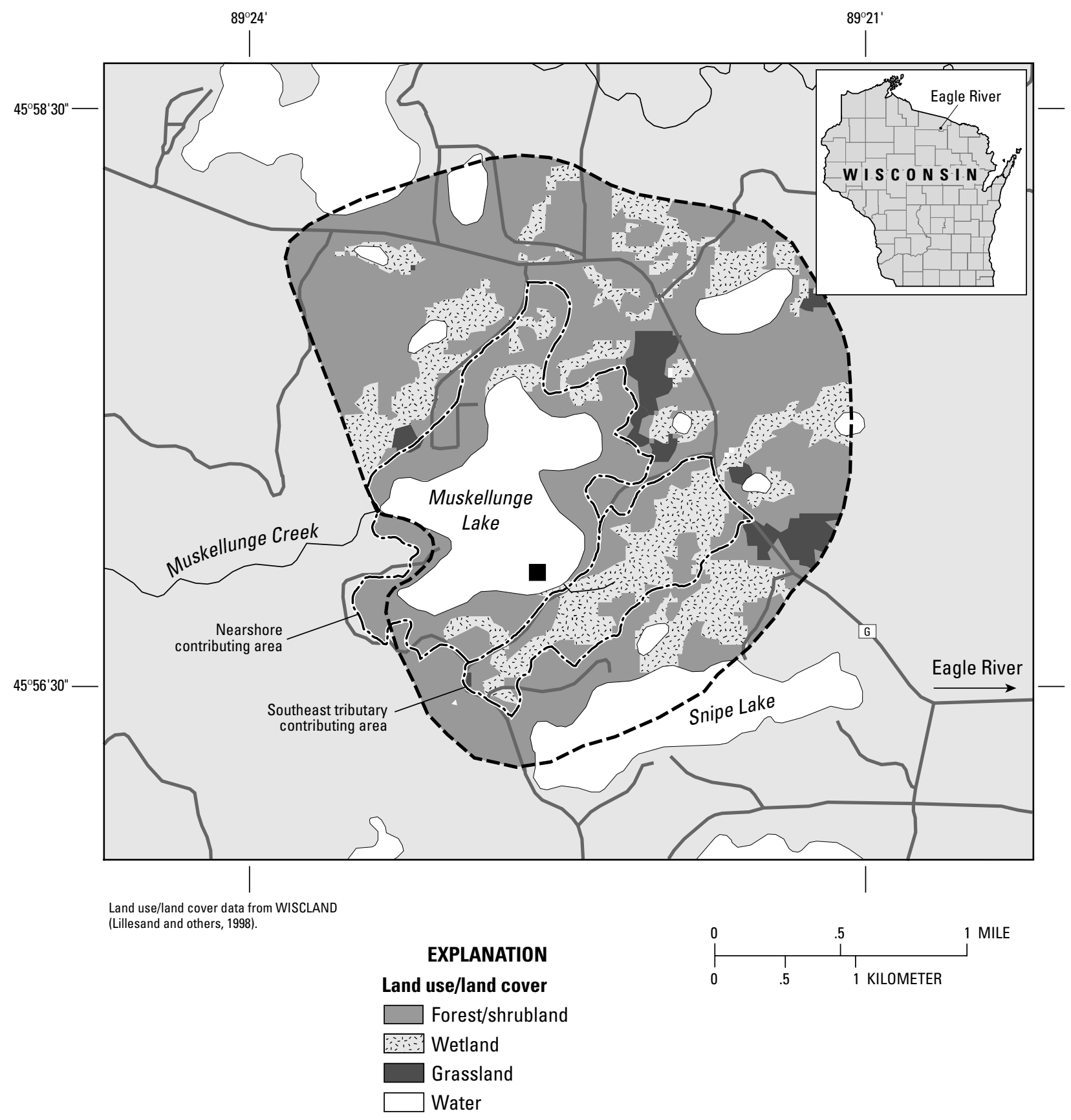

-. Surface-water contributing area

- Ground-water contributing area

Road

Aerator

Figure 1. Muskellunge Lake, Wisconsin, and surrounding area, with surface-water and ground-water contributing areas identified. 
The area of the watershed contributing surface water to Muskellunge Lake, defined by examining USGS topographic maps, is about 550 acres (fig. 1). The area contributing ground water to the lake, as determined from a ground-water-flow model constructed for the area (described later in this report), is much larger than the area contributing surface water and is about 2,200 acres (fig. 1). The area is predominantly forest and wetlands, although areas of low-density residential development are increasing. The soils in the area consist mainly of well-drained sand and sandy loams and are thought to be naturally high in phosphorus content (Wisconsin Department of Natural Resources, 1985).

\section{Data-Collection Sites and Techniques}

Data describing the water quality of the lake were collected in 1960 by the Wisconsin Conservation Department, from 1973 to 1975 by the WDNR, in 1984 by the U.S. Environmental Protection Agency, from 1992 to 1999 by the Muskellunge Lake Association, and from June 2000 to March 2002 by the USGS as part of this study. Generally, three measurements have been used to describe water quality: near-surface concentration of total phosphorus (an indicator of the amount of nutrients in the lake), nearsurface concentration of chlorophyll $a$ (an indicator of the amount of algae in the lake), and Secchi depth (an indicator of water clarity). Lake water-quality properties were usually measured during May through October near the deep hole of the lake (fig. 2). During each sampling in this study, except during March 2002, the USGS collected Secchi depth, depth profiles of water temperature, dissolved oxygen, specific conductance, and $\mathrm{pH}$ with a multiparameter instrument; near-surface samples (collected with a Van Dorn sampler) were analyzed for concentrations of total phosphorus and chlorophyll $a$ and nearbottom samples (collected just above the sediment/water interface with a Van Dorn sampler) for concentrations of total phosphorus. During spring overturn in 2001, surfacewater samples were analyzed for a full suite of waterquality constituents (U.S. Geological Survey, Wisconsin District Lake-Studies Team, 2002). During the March 2002 sampling, only profile data were collected.

Additional depth-profile measurements of temperature and oxygen were made at three secondary sampling locations (near the center of each of the bays; fig. 2) during March 2001, when oxygen depletion should be most extreme, to assess the ability of the aeration system to maintain oxygenated conditions throughout the main areas of the lake. These measurements are compared with a dissolved oxygen profile collected in late winter in 2002 when the aerator was not operated to examine the overall effects of the aeration system.

Lake water-quality data collected by the USGS as part of this study were published in the annual USGS data report series, the most recent being "Water Quality and Lake-Stage Data for Wisconsin Lakes, Water Year 2001" (U.S. Geological Survey, Wisconsin District Lake-Studies Team, 2002).

Inflow measurements were made and water samples (analyzed for total phosphorus) were collected approximately twice per month from the unnamed tributary to the lake at the culvert on Musky Road (hereafter referred to as the "southeast tributary"; fig. 2). Inflow was not continuously measured in the southeast tributary; therefore, daily flows were estimated from continuous flow measured at a nearby gaged stream (Muskellunge Creek at Birchwood Drive just upstream from Little St. Germain Lake). Coinciding measurements from the southeast tributary and Muskellunge Creek at Birchwood Drive were used to develop a relation between flows at the two sites. The regression relation and the daily flows from Muskellunge Creek were then used to estimate daily flow in the southeast tributary. Temporally varying offsets were then applied to all estimated flows to force estimated flows to equal those measured in the southeast tributary. Daily phosphorus concentrations in the southeast tributary were obtained by linearly interpolating between measured concentrations.

Daily lake stages and surface-water outflow were estimated from continuous (15-minute-interval) waterelevation measurements recorded near the dam at the outlet to Muskellunge Creek (fig. 2). Streamflow was measured approximately monthly and used to develop a stage-discharge relation for the dam, which was then used in conjunction with stage data to calculate flow from the lake. Outflow data were published in the USGS report, "Water-Resources Data, Wisconsin-Water Year 2001" (Waschbusch and others, 2002). Water samples were collected approximately monthly and analyzed for total phosphorus. Daily phosphorus concentrations were estimated by linearly interpolating between measured concentrations.

Eight small, shallow piezometers (small-diameter observation wells) were installed around Muskellunge Lake to help define areas contributing ground water to the lake and determine the phosphorus concentrations in the ground water entering the lake. The ground-water gradient 


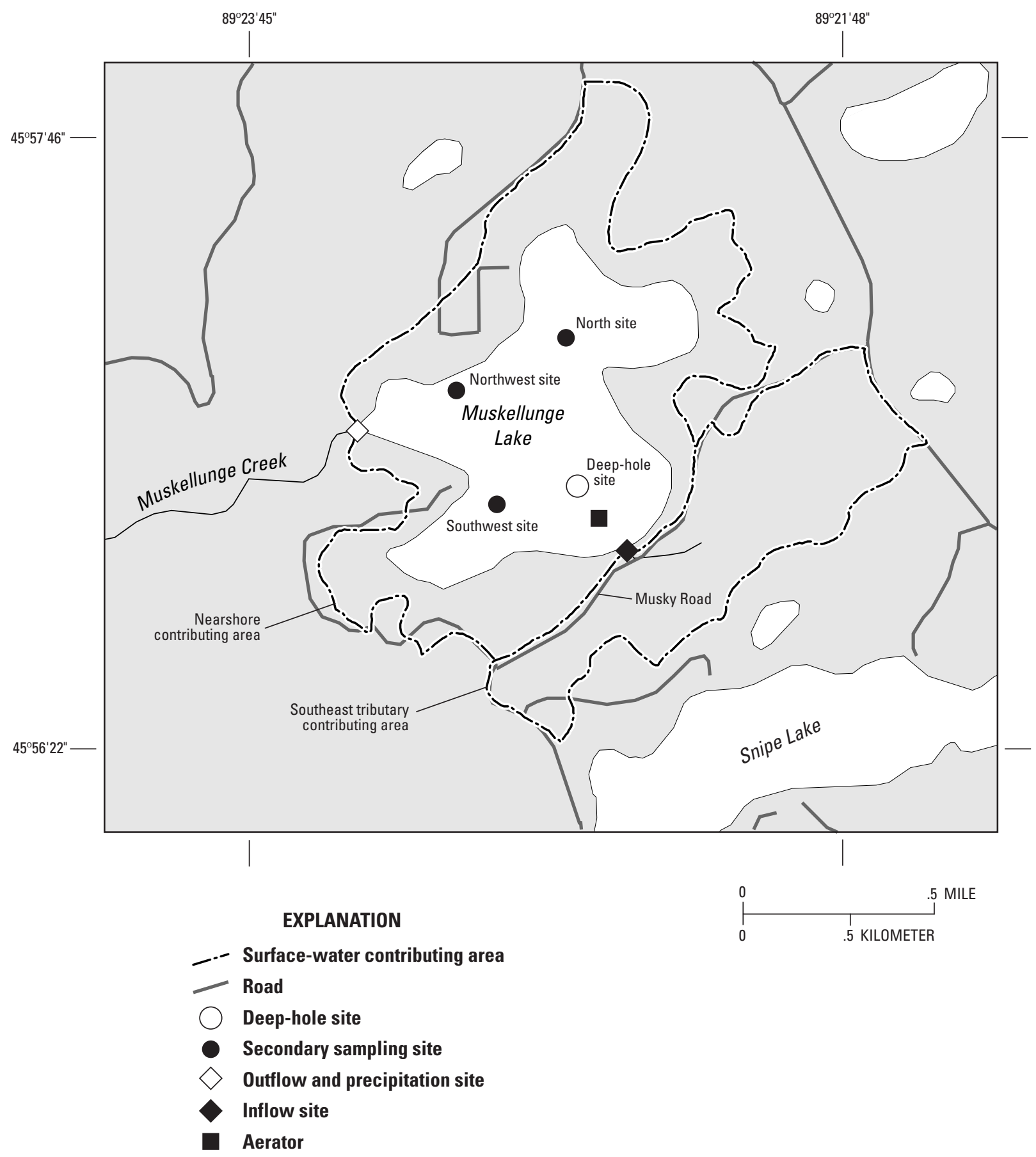

Figure 2. Data-collection sites for Muskellunge Lake, Wisconsin, and watershed boundaries. 
(determined from water elevation in the piezometer and the water elevation of the lake) and phosphorus concentrations in the ground water in each piezometer were measured three times during the study (October 2000, June 2001, and August 2001).

All chemical analyses of water samples were done by the Wisconsin State Laboratory of Hygiene in accordance with standard analytical procedures described in the "Manual of Analytical Methods, Inorganic Chemistry Unit" (Wisconsin State Laboratory of Hygiene, 1993).

\section{Lake-Water Quality}

Water-quality data collected in Muskellunge Lake confirmed that the lake was very productive and had soft water with moderate alkalinity $(36 \mu \mathrm{g} / \mathrm{L})$. The $\mathrm{pH}$ in the lake varied from about 6.7 in winter and near the bottom during stratified periods in summer to about 8 near the surface during mid to late summer. Lakes with good fish populations and productivity generally have a $\mathrm{pH}$ between 6.7 and 8.2 (U.S. Geological Survey, Wisconsin District Lake-Studies Team, 2002).

\section{Water Temperature and Dissolved Oxygen}

Thermal stratification in the lake was usually very weak, with seldom more than 2 or $3^{\circ} \mathrm{C}$ difference from the surface to the bottom. Weak stratification developed during

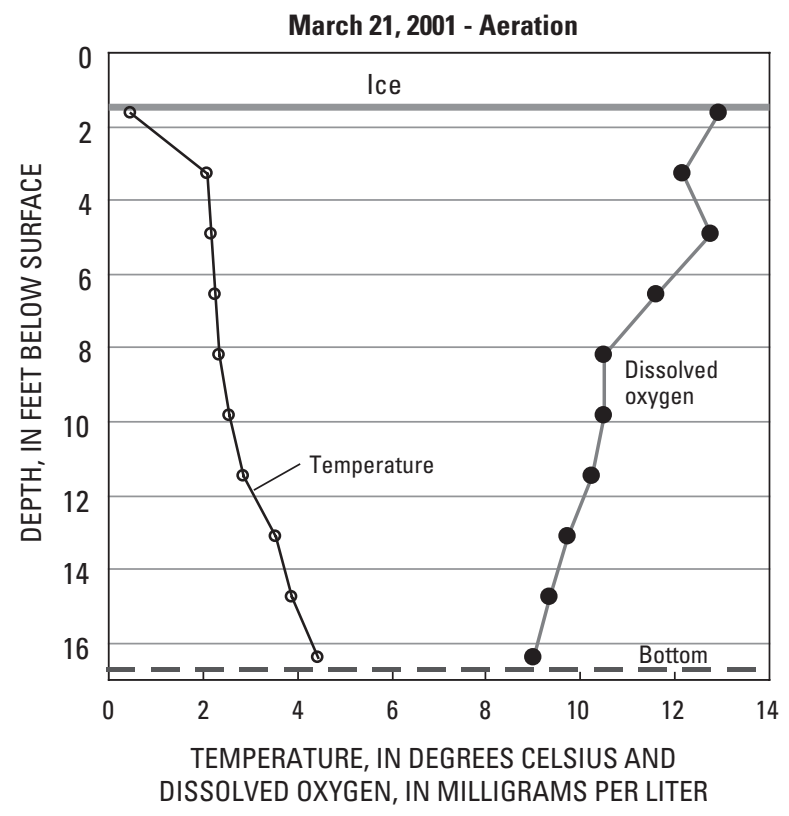

summer, but stratification usually broke down episodically during cooling periods or periods of high winds. During winter, weak thermal stratification was also present throughout the lake, even during the operation of the aeration system (fig. 3).

Although thermal stratification during summer was very weak, dissolved oxygen concentrations in the deepest water (usually only below $12 \mathrm{ft}$ ) occasionally dropped below $0.5 \mathrm{mg} / \mathrm{L}$ as a consequence of decomposition of dead algae that settled from the surface and the biochemical oxygen demand of bottom sediment.

To determine how well the aeration system maintained oxygenated conditions throughout the lake, oxygen profiles were collected near the deep hole and in each of the main bays of the lake (fig. 2) in late winter (March 21, 2001), when oxygen depletion was expected to be most extreme (fig. 4). At the deep-hole sampling site, a short distance from the aerator, dissolved oxygen concentrations were above $9 \mathrm{mg} / \mathrm{L}$ even just above the bottom. These concentrations were well above the Wisconsin state standard of $5 \mathrm{mg} / \mathrm{L}$ for dissolved oxygen in warm-water lakes (Shaw and others, 1993). Dissolved oxygen profiles in the main bays of the lake demonstrated that concentrations were above $2 \mathrm{mg} / \mathrm{L}$ throughout the lake but often below the $5 \mathrm{mg} / \mathrm{L}$ state standard. As a rule of thumb, the critical level of dissolved oxygen is about $2 \mathrm{mg} / \mathrm{L}$ for most game fish native to warmwater lakes, and levels below $1 \mathrm{mg} / \mathrm{L}$ for extended periods of time are lethal (Michigan Department of Natural Resources, 2002). To demonstrate what

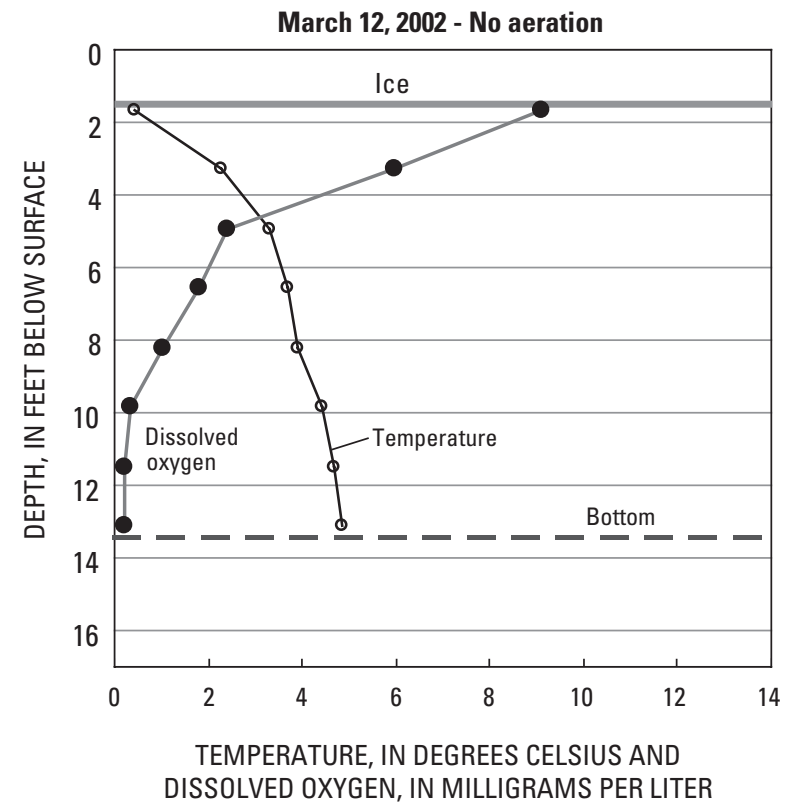

Figure 3. Water temperature and dissolved oxygen distributions near the deep hole in Muskellunge Lake, Wisconsin, on March 21, 2001 (with aeration) and March 12, 2002 (without aeration). 


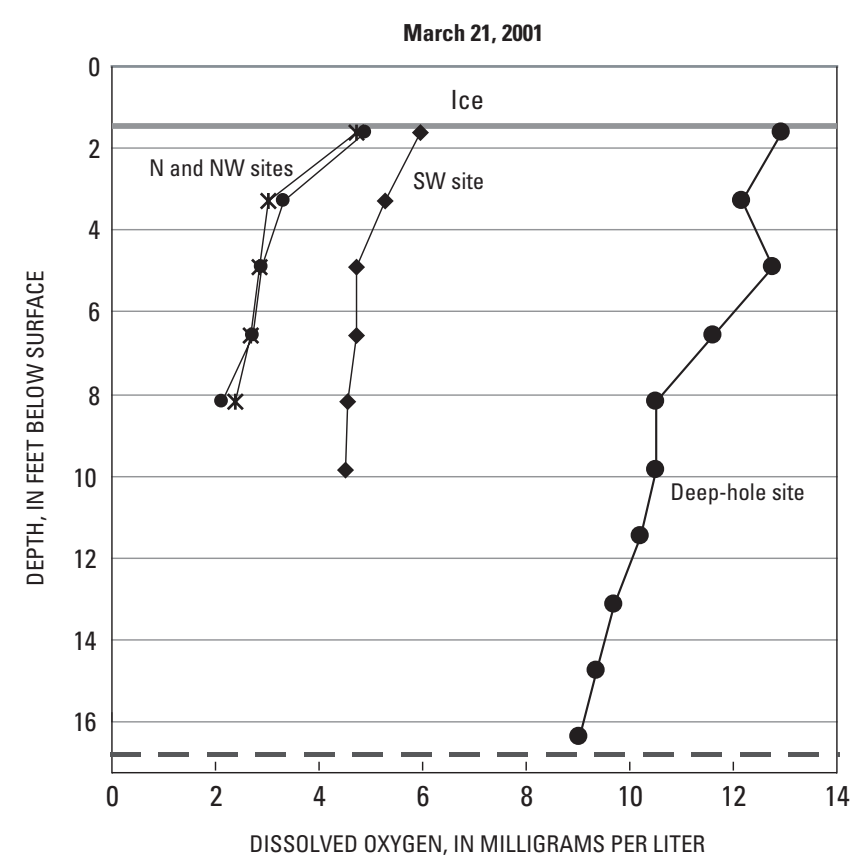

Figure 4. Dissolved oxygen distribution in several locations in Muskellunge Lake, Wisconsin, on March 21, 2001, with aeration system in operation.

oxygen concentrations would have been like if aeration was not used, these data were compared with those from late winter 2001-02 (fig. 3). In winter 2001-02, the aerator was not operated because of a late freeze and a moderately warm winter with little snow cover. Even with the conditions that favored relatively high dissolved oxygen concentrations in winter 2001-02, concentrations were less than $5 \mathrm{mg} / \mathrm{L}$ below about $4 \mathrm{ft}$ beneath the ice surface and less than $2 \mathrm{mg} / \mathrm{L}$ below about $6 \mathrm{ft}$ beneath the ice surface (fig. 3). This oxygen depletion resulted in a moderately small zone (about $4 \mathrm{ft}$ thick) from just below the ice to $6 \mathrm{ft}$ below the surface that was habitable by fish. The beneficial effects of the aerator and its importance can be seen by comparing the dissolved oxygen profiles from March 2001 (with aeration) with that from March 2002 (without aeration).

\section{Nutrient Concentrations}

Phosphorus and nitrogen are essential for plant growth and are the nutrients that usually limit algal growth in Midwestern lakes. High nutrient concentrations can cause high algal populations (blooms) and can therefore be the cause of eutrophication (that is, accelerated aging and increased productivity) of lakes. The ratio of near-surface concentrations of total nitrogen to total phosphorus is com- monly used to determine which of these nutrients should limit algal productivity in a lake. The specific value of this ratio that determines which nutrient is potentially limiting varies under different conditions such as water temperature, light intensity, and nutrient deficiencies (Correll, 1998); however, a ratio greater than about $12: 1$, by weight, usually indicates that phosphorus is the potentially limiting nutrient. The average nitrogen-to-phosphorus ratio in Muskellunge Lake ranged from 15:1 to 20:1; therefore, phosphorus should usually be the nutrient limiting algal growth in the lake and the nutrient to focus on when considering management efforts to improve water quality.

Phosphorus concentrations in Muskellunge Lake have generally ranged from about 20 to $80 \mu \mathrm{g} / \mathrm{L}$ (fig. 5). Phosphorus concentrations greater than about 17-20 $\mu \mathrm{g} / \mathrm{L}$ indicate eutrophic conditions. Concentrations were lowest in late fall, winter, and spring, and highest in late summer. Surface concentrations commonly increase throughout summer in shallow lakes because of the release of phosphorus from the sediments in deep areas of the lake that occurs during short stratified periods when these areas are depleted of oxygen. This phosphorus is subsequently mixed with the rest of the water column during periods of destratification. Short stratified periods occur in Muskellunge Lake because the lake is relatively shallow with respect to its surface area. There was a slight increase in phosphorus concentrations from a summer average concentration of 30-40 $\mu \mathrm{g} / \mathrm{L}$ in about 1996 (the earliest measurements to about 1996 were relatively stable) to about $40-50 \mu \mathrm{g} / \mathrm{L}$ in $2000-01$. Higher concentrations were, however, measured from 1997 to 1999. The average surface concentration in summer (June through August) of 2001 was $49 \mu \mathrm{g} / \mathrm{L}$.

\section{Chlorophyll a Concentrations}

Chlorophyll $a$ is a photosynthetic pigment found in algae and other green plants. Its concentration, therefore, is commonly used as a measure of the density of the algal population in a lake. Concentrations greater than about $7-10 \mu \mathrm{g} / \mathrm{L}$ indicate eutrophic conditions and greater than 20-30 $\mu \mathrm{g} / \mathrm{L}$ are usually considered to be associated with algal blooms. Chlorophyll $a$ concentrations ranged from $5-10 \mu \mathrm{g} / \mathrm{L}$ in early summer to $30-50 \mu \mathrm{g} / \mathrm{L}$ in late summer, with the highest concentration of $91 \mu \mathrm{g} / \mathrm{L}$ measured in August 1999 (fig. 5). The average concentration in the summer of 2001 was $19 \mu \mathrm{g} / \mathrm{L}$. 

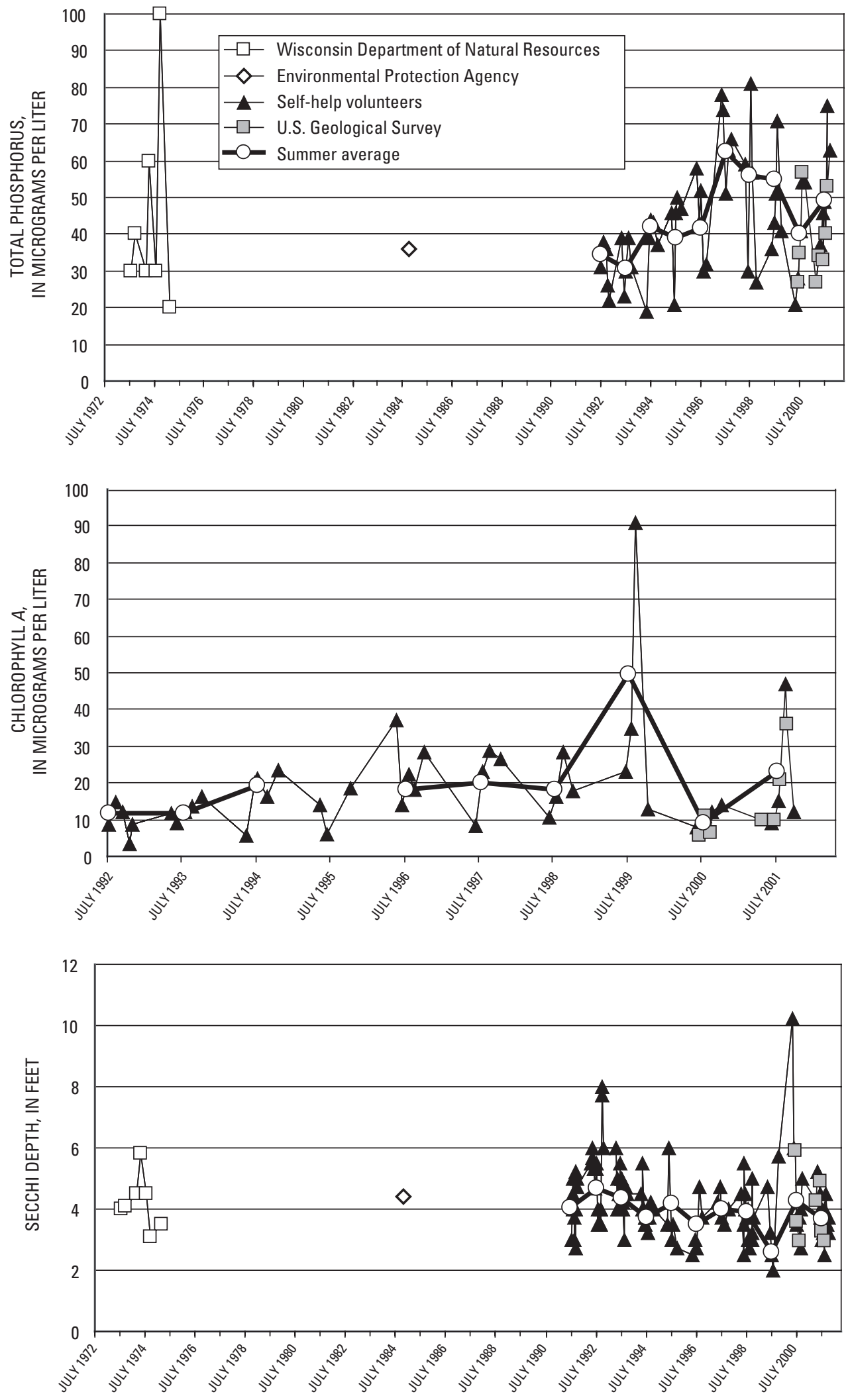

Figure 5. Concentrations of total phosphorus and chlorophyll a, and Secchi depths near the deep hole in Muskellunge Lake, Wisconsin. 


\section{Water Clarity}

Water clarity, based on Secchi depth measurements, generally ranged from 2 to $6 \mathrm{ft}$; however, on a few occasions (1992 and 2000) it exceeded $8 \mathrm{ft}$ (fig. 5). Secchi depths less than $6 \mathrm{ft}$ indicate eutrophic conditions. Water clarity was typically best in spring and fall and decreased as summer progressed. The average summer Secchi depth was about $4 \mathrm{ft}$ and has not changed throughout the period of measurements. In 1999, however, the average summer Secchi depth decreased to $2.6 \mathrm{ft}$. The average summer Secchi depth in 2001 was $3.6 \mathrm{ft}$.

\section{Trophic State Indices}

One method of classifying the water quality or productivity of a lake is by computing water-quality indices such as Trophic State Indices (TSIs). These indices, based on near-surface concentrations of total phosphorus and chlorophyll $a$ and on Secchi depths, were developed by Carlson (1977) and modified for Wisconsin lakes by Lillie and others (1993). These indices were developed to place these three characteristics on similar scales. Oligotrophic lakes (TSIs less than 40) typically have a limited supply of nutrients, clear water, low algal populations, low phosphorus concentrations, and the deepest water in the lake typically contains oxygen throughout the year. Mesotrophic lakes (TSIs between 40 and 50) typically have a moderate supply of nutrients, are prone to moderate algal blooms, and have occasional oxygen depletions at depth. Eutrophic lakes (TSIs greater than 50) are nutrient rich with correspondingly severe water-quality problems, such as frequent seasonal algal blooms, oxygen depletion in the deeper areas of the lakes, and poor clarity. Lakes with TSIs greater than 60 are considered hypereutrophic and usually have extensive algal blooms during summer. All three indices indicate that Muskellunge Lake was usually eutrophic and often hypereutrophic (fig. 6). The TSIs indicate that the only time the lake would have been considered mesotrophic was in early summer and late fall. All three indices were relatively high in 1997 to 1999 . Lower values occurred prior to 1997 and after 1999. The higher TSI values in 1997 to 1999 may have been caused by the longer growing season in these years associated with warmer springs and earlier ice-out dates.

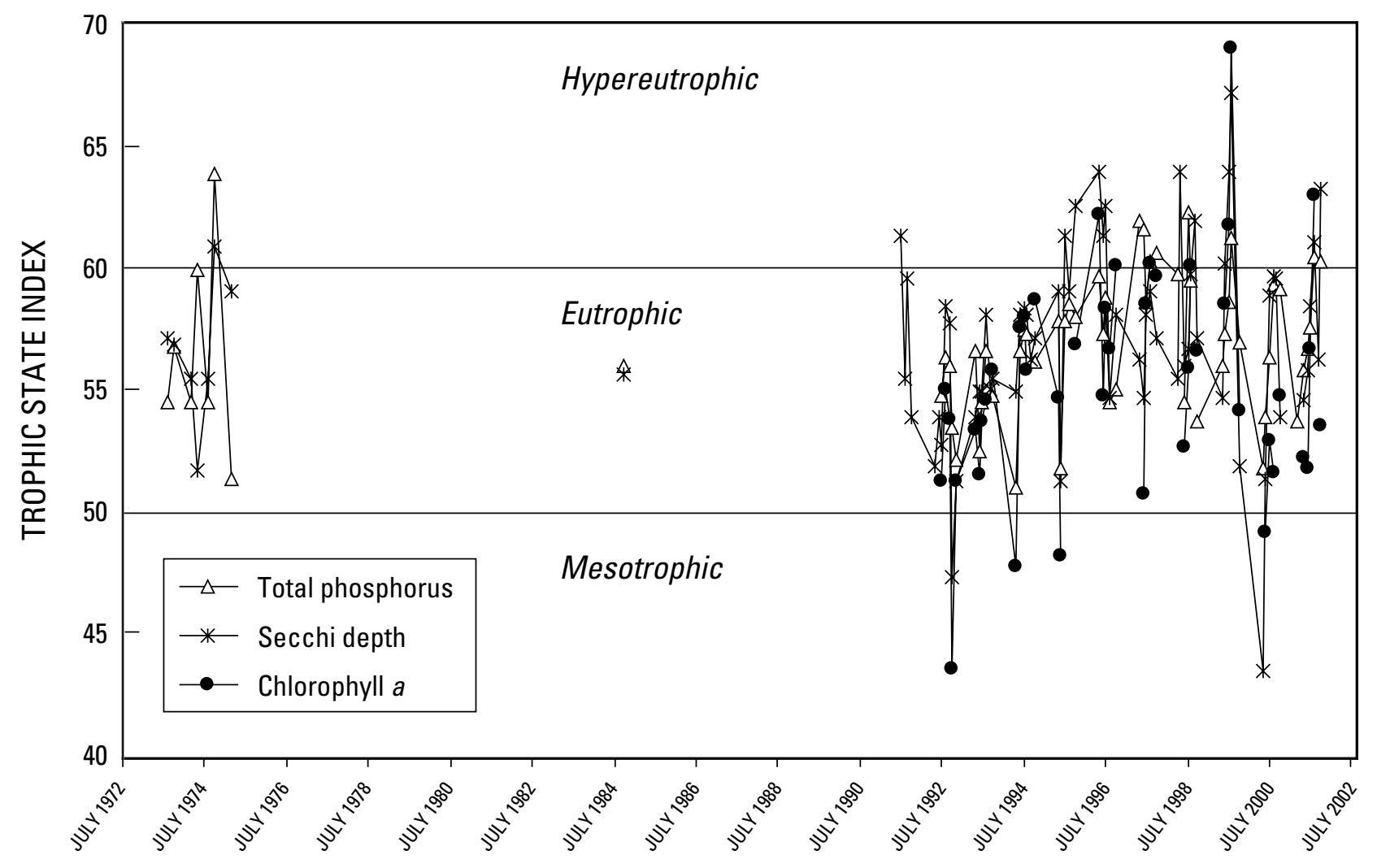

Figure 6. Trophic state indices based on surface concentrations of total phosphorus and chlorophyll $a$, and Secchi depths collected near the deep hole in Muskellunge Lake, Wisconsin. 


\section{Sources of Water and Phosphorus to Muskellunge Lake}

Because productivity in Muskellunge Lake should be limited by the input of phosphorus (based on nitrogento-phosphorus ratios), reduction in phosphorus input to the lake would be a logical management goal. Most of the phosphorus enters the lake associated with the input of water. Therefore, to determine where the water and phosphorus originates and how changes in phosphorus loading would affect the trophic status of the lake, we first quantified the water and phosphorus budgets of the lake.

\section{Water}

The hydrology of Muskellunge Lake can be described in terms of components of its water budget (fig. 7). The water budget for the lake may be represented by the equation:

$$
\Delta \mathrm{S}=\left(\mathrm{PPT}+\mathrm{SW}_{\mathrm{In}}+\mathrm{GW}_{\text {In }}\right)-\left(\text { Evap }+\mathrm{SW}_{\text {Out }}+\mathrm{GW}_{\text {Out }}\right),
$$

where $\Delta \mathrm{S}$ is the change in the volume of water stored in the lake during the period of interest and is equal to the sum of the volumes of water entering the lake minus the sum of the volumes leaving the lake. Water enters the lake as precipitation (PPT), surface-water inflow $\left(\mathrm{SW}_{\mathrm{In}}\right)$, and ground-water inflow $\left(\mathrm{GW}_{\mathrm{In}}\right)$. Water leaves the lake through evaporation (Evap), surface-water outflow ( $\left.\mathrm{SW}_{\text {Out }}\right)$, and ground-water outflow $\left(\mathrm{GW}_{\text {Out }}\right)$.

Each term in the water budget was computed on a daily basis from November 1, 2000 to October 31, 2001. Changes in lake volume were determined from lake stages monitored near the outlet dam (fig. 2), assuming a constant surface area of the lake. Lake stage fluctuated from a minimum of $9.94 \mathrm{ft}$ (relative to an arbitrary datum) in early September to a maximum of $10.55 \mathrm{ft}$ in late April (fig. 8). The lake stage was relatively stable from November through early April, rose rapidly by about $0.3 \mathrm{ft}$ during April, decreased gradually throughout summer, and then gradually increased starting in September. The lake stage at the end of October 2001 was $0.10 \mathrm{ft}$ higher than at the beginning of the 1-year period (table 1).

During the ice-free period, precipitation was measured continuously near the outlet dam. For the remainder of the period, daily precipitation was interpolated from data collected by weather observers in St. Germain, Eagle River, and near Lower Buckatabon Lake. The total annual precipitation was 30.69 in. (table 1), which is near the long-term average for the area.

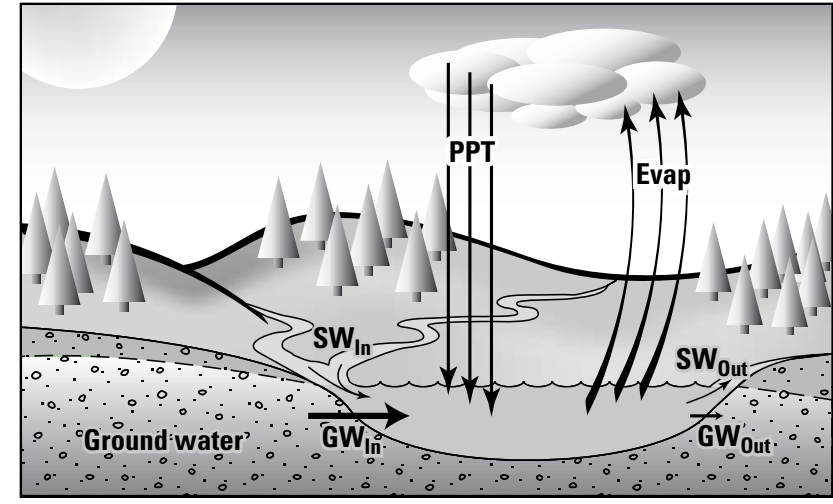

Figure 7. Schematic of the hydrologic cycle of Muskellunge Lake, Wisconsin. Abbreviations are defined in the text.

Surface-water inflow was divided into that from the southeast tributary (drainage area of 227 acres) and that from the remaining nearshore areas (323 acres). Inflow measurements were made approximately two times per month from the southeast tributary and used to develop a relation with daily flows collected by the USGS at Muskellunge Creek at Birchwood Drive (just upstream of Little St. Germain Lake). Daily flows at Birchwood Drive were then used to estimate daily inflows from the southeast tributary. The total annual input from the southeast tributary was 575 acre-ft, which equates to a change in water level in the lake of about 25 in. (table 1). The southeast tributary accounts for most of the surface-water input to the lake, except during snowmelt.

Surface inflow from the remaining nearshore areas was estimated by three different methods for three different periods of the year: non-snow-covered period, winter snow-covered period, and spring snowmelt period. A 0.0015 runoff/rainfall coefficient was used to estimate daily runoff during non-snow-covered periods. This coefficient was the average coefficient determined for six intensively monitored, forested plots in Vilas County (D. Graczyk, U.S. Geological Survey, written commun., 2002). For the winter period, it was assumed that there was no nearshore runoff from these areas. For the snowmelt period, defined as the 30-day period from April 6 through May 5, runoff was estimated by comparing the measured lake stage with stage calculated using equation 1. During this 30-day period, $0.48 \mathrm{ft}$ of water was needed on the lake surface to maintain the observed and calculated lake stages tracking near and parallel to each other (fig. 8). For simplicity, the total runoff was distributed uniformly through time (0.19 in/d), although actual runoff during this period 


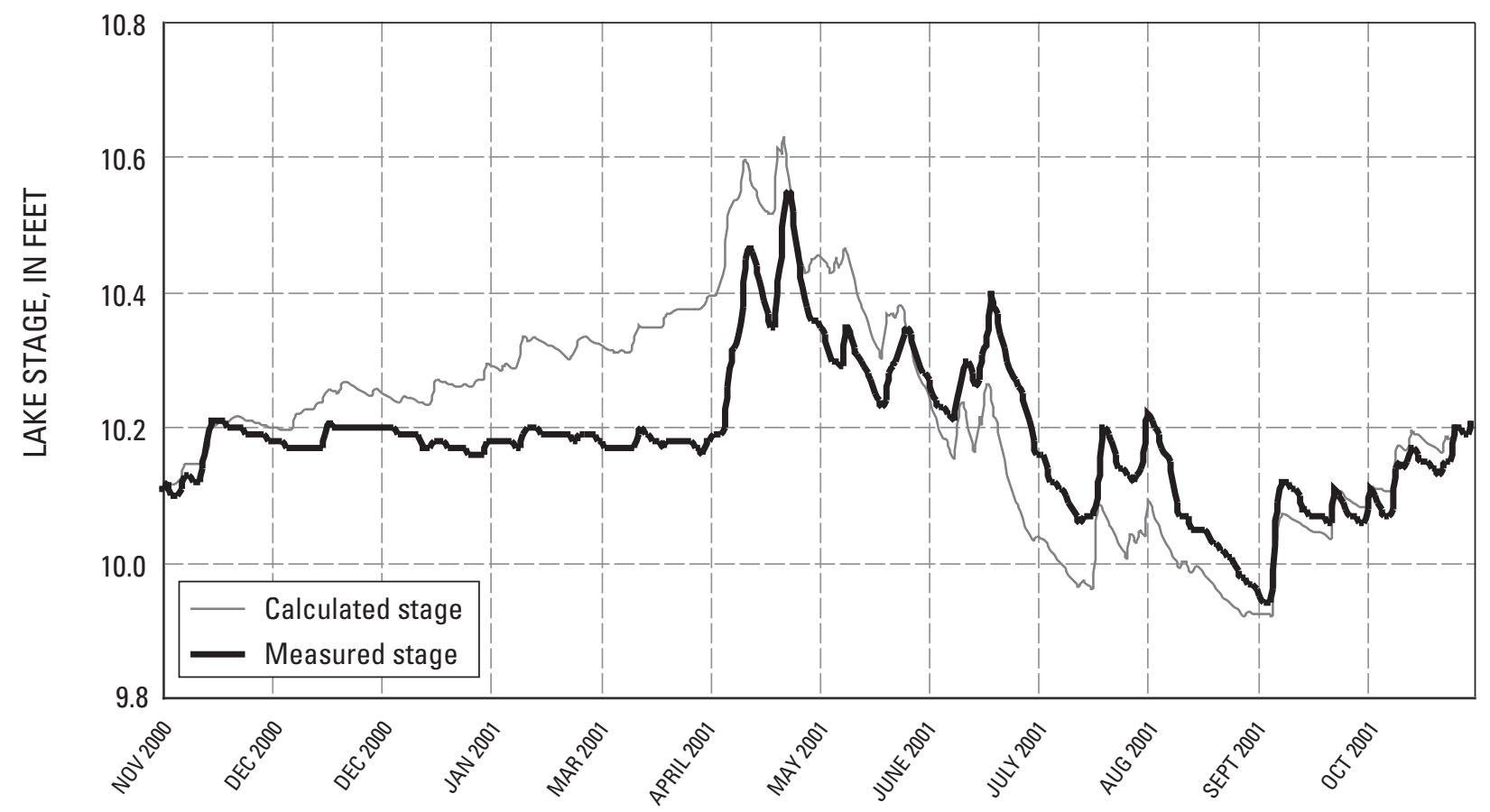

Figure 8. Daily average lake stages (measured and calculated) of Muskellunge Lake, Wisconsin.

Table 1. Monthly water budget for Muskellunge Lake, Wisconsin, November 1, 2000 to October 31, 2001, in inches on the surface of the lake

\begin{tabular}{|c|c|c|c|c|c|c|c|}
\hline \multirow[b]{2}{*}{ Month } & \multicolumn{4}{|c|}{ Inputs } & \multicolumn{3}{|c|}{ Outputs } \\
\hline & Precipitation & $\begin{array}{c}\text { Southeast } \\
\text { tributary }\end{array}$ & $\begin{array}{c}\text { Remaining } \\
\text { nearshore } \\
\text { areas }\end{array}$ & Ground water & Evaporation & $\begin{array}{c}\text { Muskellunge } \\
\text { Creek }\end{array}$ & $\begin{array}{c}\text { Change in } \\
\text { storage }\end{array}$ \\
\hline November & 1.77 & 2.13 & 0.00 & 4.91 & 0.47 & 7.24 & 0.07 \\
\hline December & 1.27 & 1.56 & .00 & 5.08 & .00 & 7.27 & .02 \\
\hline January & 1.22 & .77 & .00 & 5.08 & .00 & 6.61 & -.02 \\
\hline February & 1.43 & .60 & .00 & 4.59 & .00 & 6.17 & .01 \\
\hline March & .81 & 1.44 & .00 & 5.08 & .00 & 6.75 & -.03 \\
\hline April & 5.32 & 5.64 & 4.80 & 4.91 & .82 & 19.00 & .20 \\
\hline May & 3.88 & 4.58 & .96 & 5.08 & 3.70 & 13.03 & -.08 \\
\hline June & 4.68 & 3.21 & .01 & 4.91 & 4.09 & 11.36 & -.07 \\
\hline July & 3.36 & 1.81 & .00 & 5.08 & 4.21 & 5.96 & -.07 \\
\hline August & 1.44 & .52 & .00 & 5.08 & 3.62 & 4.90 & -.17 \\
\hline September & 2.86 & 1.29 & .00 & 4.91 & 2.80 & 4.38 & .09 \\
\hline October & 2.65 & 1.82 & .00 & 5.08 & 2.05 & 5.99 & .15 \\
\hline Total, in inches & 30.69 & 25.38 & 5.78 & 59.77 & 21.77 & 98.65 & .10 \\
\hline Total, in acre-feet & 695 & 575 & 131 & 1,350 & 493 & 2,230 & 2.30 \\
\hline
\end{tabular}


was quite variable. The total inflow from these remaining nearshore areas was estimated to be 131 acre-ft, which equates to a change in water level of about 6 in.

Evaporation from the lake was estimated from average monthly evaporation-pan data from 12 years of data collected at the Rainbow Flowage about 16 mi west of Muskellunge lake. Monthly lake/pan coefficients computed as part of a study on Vandercook Lake, Vilas County (Wentz and Rose, 1991), were used to adjust the pan evaporation rates to obtain total lake evaporation. These coefficients ranged from 0.75 in May to 1.17 in October. No evaporation was assumed to occur when the lake was ice covered. About 22 in. of water was estimated to have evaporated from the lake during this period (table 1), most of which occurred during summer. Surface-water outflow consisted of flow over the dam into Muskellunge Creek. There was a total annual output of 2,230 acre-ft through Muskellunge Creek, which equates to about 99 in. from the surface of the lake.

Ground-water gradients from the piezometers installed around the lake (fig. 9) and a two-dimensional, analytic-element, steady-state, ground-water-flow model, GFLOW (Haitjema, 1995), were used to define groundwater-source areas and to allocate ground-water discharge to shoreline segments represented by the eight piezometers. A description of the ground-water model is beyond the scope of this report, but can be found in Haitjema (1995). The GFLOW model covered an area extending approximately 3 to $6 \mathrm{mi}$ around Muskellunge Lake. The model was calibrated by varying horizontal hydraulic conductivity and ground-water recharge within an expected range until there was a reasonable match between measured and simulated ground-water levels and stream base flows in the area. Areal recharge to the ground-water system was set equal to $9 \mathrm{in} / \mathrm{yr}$ and horizontal hydraulic conductivity was set equal to $28 \mathrm{ft} / \mathrm{d}$ for the calibrated model. These values are similar to those used by Hunt and others (1998) for another area in Vilas County. For 46 water-level targets, the calibrated model had a mean difference between measured and simulated water levels of $0.1 \mathrm{ft}$ and mean absolute difference of $3.6 \mathrm{ft}$. Simulated base flows were within $0.5 \mathrm{ft}^{3} / \mathrm{s}$ of measured base flows at Muskellunge Creek at Birchwood Drive and Little St. Germain Creek at Highway 70.

The ground-water contributing area for Muskellunge Lake was delineated using particle-tracking techniques in GFLOW. The area contributing ground water to the lake is much larger than that contributing surface water and covers approximately 2,200 acres (figs. 1 and 9). Ground water discharges into the lake from all sides except for two small areas during certain periods of the year, based on hydraulic-head measurements made in the piezometers around Muskellunge Lake (fig. 9). Along a segment of the shoreline near the outlet of the lake represented by piezometer 3 and along a segment of the south shoreline represented by piezometers 5 and 6 , ground-water gradients were slight but toward the lake most of the time. For a brief 1- to 2-month period in late summer, ground-water gradients were slightly negative or away from the lake in areas near these piezometers. On an annual basis this outflow would be slight. Ground-water flow simulated by GFLOW also demonstrated that ground water enters the lake from all areas except near piezometers 3 and 4 . Hence, $\mathrm{GW}_{\text {Out }}$ was assumed to be negligible and was omitted from the water budget (table 1).

A total ground-water input to the lake of 1,350 acre$\mathrm{ft}$, which equates to $1.87 \mathrm{ft}^{3} / \mathrm{s}$ or a change in water level of about $60 \mathrm{in}$. (table 1), was computed as the residual in the water-budget equation (eq. 1). Ground-water flow to the lake was assumed to be uniform throughout the year, although in reality there is seasonal variation. The separation of the calculated and measured stage graphs in figure 8 is likely a reflection of actual seasonal variation in ground-water flow to the lake.

GFLOW simulated a total ground-water discharge to the lake of $2.48 \mathrm{ft}^{3} / \mathrm{s}$, whereas $\mathrm{GW}_{\mathrm{In}}$, calculated as the residual in the water budget, was $1.87 \mathrm{ft}^{3} / \mathrm{s}$. The simulated ground-water flux into the lake was calculated for eight shoreline segments, each corresponding to the length of shoreline halfway between adjacent piezometers installed around the lake. The model developed for the area did not include the southeast tributary. For this reason, ground water that actually discharges to the tributary was simulated as discharge to the lake in the shoreline segments near piezometers 5,6 , and 7 . It was estimated that about 75 percent, or $0.59 \mathrm{ft}^{3} / \mathrm{s}$, of flow from the southeast tributary is base flow (ground-water discharge). Therefore, the $0.59 \mathrm{ft}^{3} / \mathrm{s}$ was proportionately subtracted from the model-indicated flows to shoreline segments represented by piezometers 5,6 , and 7 . The total ground-water input to the lake was then $1.87 \mathrm{ft}^{3} / \mathrm{s}$. The amount of ground water entering the lake through each shoreline segment is represented by the thickness of the segment lines around the lake in figure 9. Ground-water flux into the lake ranged from $0.02 \mathrm{ft}^{3} / \mathrm{s}$ (shoreline segment near piezometer 4) to $0.63 \mathrm{ft}^{3} / \mathrm{s}$ (shoreline segment near piezometer 1 ). More than 65 percent of the ground water is estimated to enter the lake through the north shore (represented by piezometers 1 and 8). 


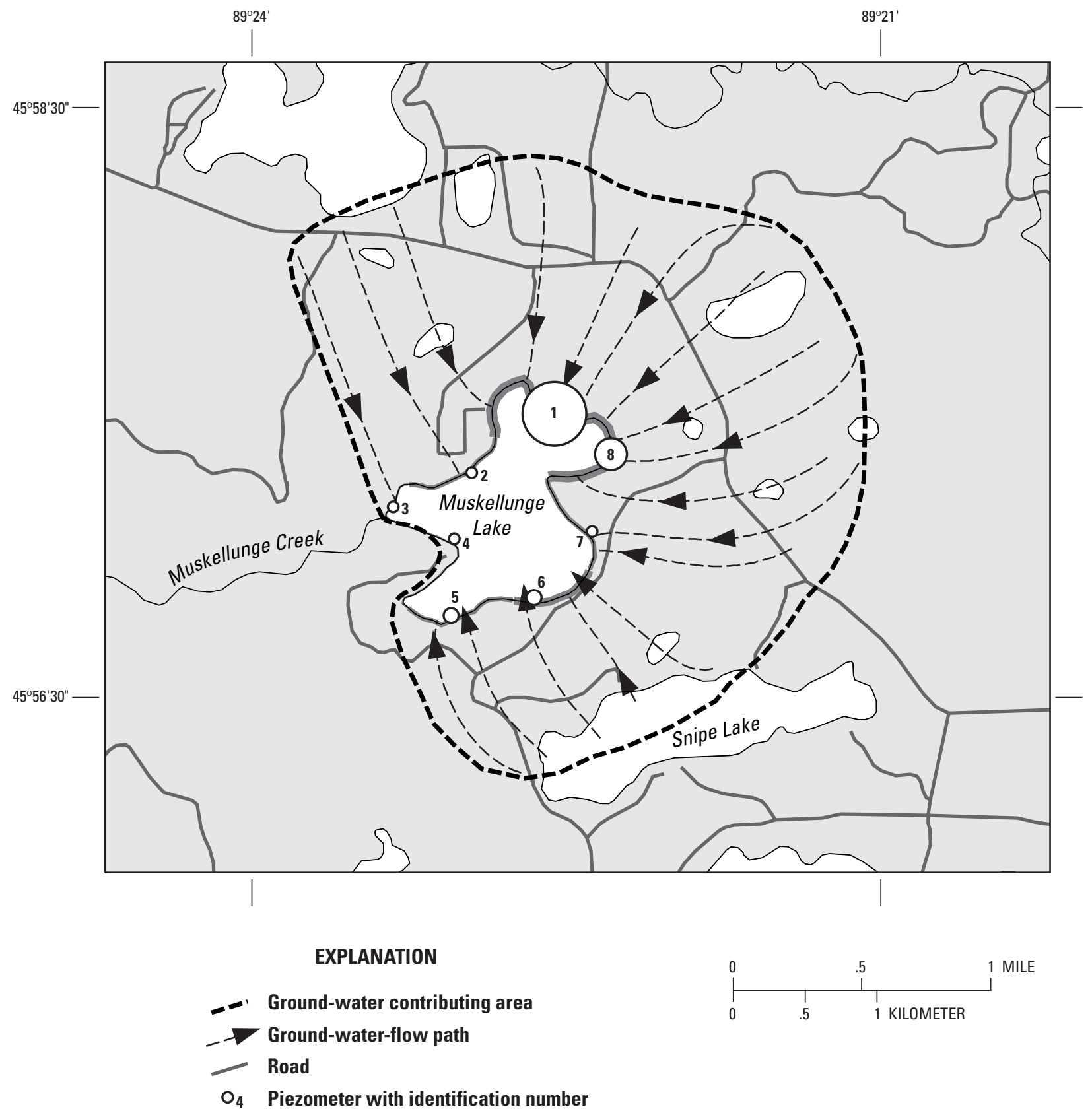

Figure 9. Ground-water-flow paths to Muskellunge Lake, Wisconsin. The relative amount of ground water entering the lake is demonstrated by the width of shoreline segments. The relative amount of phosphorus loading per shoreline segment is demonstrated by the size of the circle at each piezometer location. 
The complete daily water budget fairly accurately simulated the changes in the water level of the lake (fig. 8). The largest error in the hydrologic balance of the lake was about $0.2 \mathrm{ft}$. The complete water budget (fig. 10) indicated that from November 1, 2000 to October 31, 2001, groundwater inflow was the major source of water to the lake (49 percent of the total inputs). Direct precipitation contributed 25 percent of the total input, whereas surfacewater inflow from the southeast tributary and other nearshore areas contributed 26 percent of the total input. The major loss of water from the lake was through the outlet (81 percent), whereas 18 percent was lost through evaporation and 1 percent went into increased storage in the lake.

\section{Phosphorus}

To help define where the phosphorus in Muskellunge Lake originates, a detailed phosphorus budget was computed for this 1-year period. Sources of phosphorus to the lake include precipitation, surface-water inflow, ground water, and contributions from septic systems. The phosphorus concentration in precipitation was assumed to be constant at $7 \mu \mathrm{g} / \mathrm{L}$, a value suggested by Rose (1993) for northern Wisconsin. Therefore, direct precipitation contributed about $13 \mathrm{lb}$ of phosphorus to the lake during the study year (table 2).

Phosphorus concentrations were measured approximately monthly and more frequently during flow events in the southeast tributary. Concentrations were generally lowest from October through June $(20-40 \mu \mathrm{g} / \mathrm{L})$ and then steadily increased throughout summer, reaching about $90 \mu \mathrm{g} / \mathrm{L}$ in late August. During a high-flow event in July, however, a concentration of $177 \mu \mathrm{g} / \mathrm{L}$ was measured. Daily phosphorus concentrations in the southeast tributary were obtained by linearly interpolating between measurements. The phosphorus concentration in runoff from the remaining nearshore areas that are predominantly forested was assumed to be $100 \mu \mathrm{g} / \mathrm{L}$, based on six intensively monitored, forested plots in Vilas County (D. Graczyk, U.S. Geological Survey, written commun., 2002). The amount of phosphorus delivered to the lake was then computed by multiplying the daily phosphorus concentrations by the daily inflow volumes. The total input of phosphorus from the southeast tributary and remaining nearshore areas was estimated to be about 65 and $36 \mathrm{lb}$, respectively (table 2). Over 50 percent of the phosphorus loading from surface inflow occurred in April and May.

Dissolved phosphorus concentrations were measured in the eight piezometers installed around the lake (fig. 9) three times during the study period. Phosphorus concentrations varied only slightly at each location. The average phosphorus concentration was highest on the north side of the lake (131 $\mu \mathrm{g} / \mathrm{L}$, piezometer 1$)$. Moderate concentrations were measured on the east and southeast sides of the lake ( 26 to $50 \mu \mathrm{g} / \mathrm{L}$, piezometers $5,6,7$, and 8 ). Lowest concentrations were measured on the west side of the lake (13 to $17 \mu \mathrm{g} / \mathrm{L}$, piezometers 2,3 , and 4 ). The input of phosphorus was then computed by multiplying the average
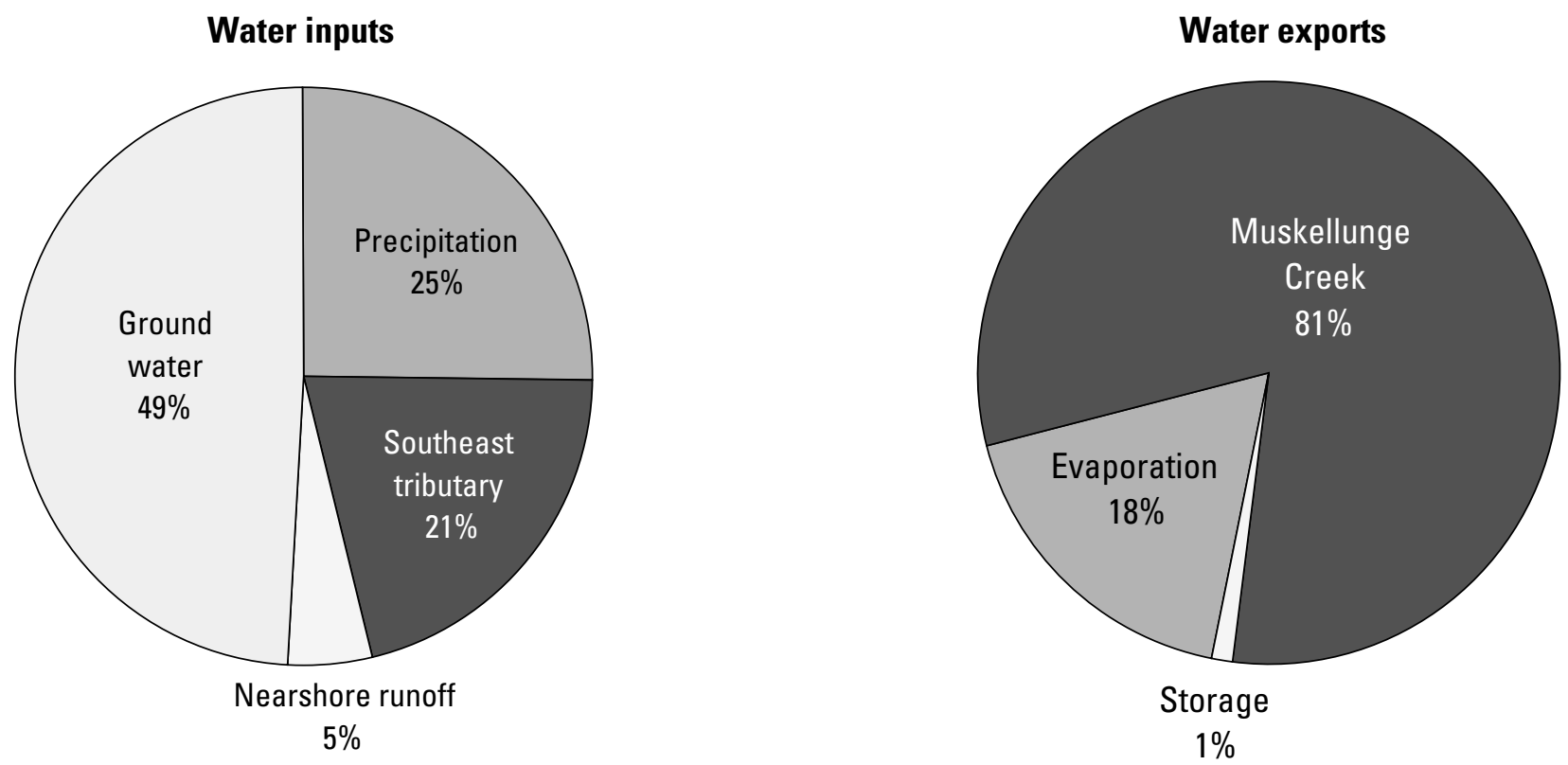

Figure 10. Water budget for Muskellunge Lake, Wisconsin, November 1, 2000 to October 31, 2001. 
phosphorus concentration from each piezometer by the ground-water flux computed for each shoreline segment. Ground water was estimated to contribute about $250 \mathrm{lb}$ of phosphorus during the period (table 2). The relative amount of phosphorus contributed through each shoreline segment is demonstrated in figure 9 by the size of the circle around the piezometer number. Annual phosphorus loading from ground water ranged from $0.4 \mathrm{lb}$ (shoreline segment near piezometer 4) to $172 \mathrm{lb}$ (shoreline segment near piezometer 1). Most phosphorus enters from the north side of the lake where flow and phosphorus concentrations were both highest. Most of this phosphorus appears to be from natural sources because the highest concentrations were found where there is little development.

The input of phosphorus from septic systems (M) was estimated by use of equation 2 (Reckhow and others, 1980):

$$
\mathrm{M}=\mathrm{E}_{\mathrm{S}} * \text { (number of capita years) } *\left(1-\mathrm{S}_{\mathrm{R}}\right)
$$

where $\mathrm{M}$ is a function of an export coefficient, $\mathrm{E}_{\mathrm{S}}$, and a soil retention coefficient, $S_{R}$. In applying equation 2 , it was assumed that the most likely value for $\mathrm{E}_{\mathrm{S}}$ was $1.5 \mathrm{lb}$ of phosphorus per capita per year. Typical export coefficients range from $1.1 \mathrm{lb}$ per capita per year (Reckhow and others, 1980; Panuska and Kreider, 2002) to $1.8 \mathrm{lb}$ per capita per year (Garn and others, 1996). The number of capita years was estimated to be 150 (50 full-year residents and 400 three-month residents), and the most likely value of $S_{R}$ was 0.7 (70 percent). The total input from septic tanks was then computed to be $69 \mathrm{lb}$ per year. Because inputs from septic systems were not directly measured, low and high estimates for this value were obtained by applying high and low estimates for $S_{R}(0.9$ and 0.5$)$. The possible low and high estimates of phosphorus from septic systems were 23 and $83 \mathrm{lb}$, respectively. These values may overestimate the contributions from septic systems because many residents live in areas with little ground-water flow to the lake (southwestern side of the lake, fig. 9).

The phosphorus concentration in the water leaving the lake was measured approximately monthly. Concentrations in the outflow were similar to that in the lake and were generally lowest in winter and early spring (20-30 $\mu \mathrm{g} / \mathrm{L})$ and highest in mid summer (45-60 $\mu \mathrm{g} / \mathrm{L}$, in July). Daily phosphorus concentrations were obtained by linearly interpolating between measurements. The total phosphorus exported from the lake was then computed by multiplying the daily phosphorus concentrations by the daily flow in Muskellunge Creek. The total output of phosphorus from Muskellunge Creek was estimated to be $206 \mathrm{lb}$ (table 2).

Table 2. Monthly phosphorus budget for Muskellunge Lake, Wisconsin, November 1, 2000 to October 31, 2001, in pounds

\begin{tabular}{|c|c|c|c|c|c|c|}
\hline \multirow[b]{2}{*}{ Month } & \multicolumn{5}{|c|}{ Inputs } & \multirow{2}{*}{$\begin{array}{c}\text { Outputs } \\
\begin{array}{c}\text { Muskellunge } \\
\text { Creek }\end{array}\end{array}$} \\
\hline & Precipitation & $\begin{array}{c}\text { Southeast } \\
\text { tributary }\end{array}$ & $\begin{array}{c}\text { Remaining } \\
\text { nearshore } \\
\text { areas }\end{array}$ & $\begin{array}{l}\text { Ground } \\
\text { water }\end{array}$ & $\begin{array}{c}\text { Septic } \\
\text { systems }\end{array}$ & \\
\hline November & 0.8 & 3.3 & 0.0 & 20.8 & 5.7 & 11.1 \\
\hline December & .5 & 2.5 & .0 & 21.5 & 5.9 & 9.0 \\
\hline January & .5 & 1.3 & .0 & 21.5 & 5.9 & 5.8 \\
\hline February & .6 & 1.1 & .0 & 19.4 & 5.3 & 7.9 \\
\hline March & .3 & 2.6 & .0 & 21.5 & 5.9 & 12.0 \\
\hline April & 2.3 & 13.9 & 29.5 & 20.8 & 5.7 & 36.9 \\
\hline May & 1.7 & 9.8 & 5.9 & 21.5 & 5.9 & 26.7 \\
\hline June & 2.0 & 10.7 & .0 & 20.8 & 5.7 & 31.5 \\
\hline July & 1.4 & 9.6 & .0 & 21.5 & 5.9 & 20.5 \\
\hline August & .6 & 2.9 & .0 & 21.5 & 5.9 & 12.1 \\
\hline September & 1.2 & 4.0 & .0 & 20.8 & 5.7 & 13.9 \\
\hline October & 1.1 & 3.7 & .0 & 21.5 & 5.9 & 19.1 \\
\hline Total & 13.2 & 65.3 & 35.6 & 253.5 & 69.4 & 206.4 \\
\hline
\end{tabular}


The complete phosphorus budget (fig. 11) indicates that $437 \mathrm{lb}$ of phosphorus were input into Muskellunge Lake from November 1, 2000 to October 31, 2001. Input from ground water was the major source of phosphorus to the lake (58 percent). The secondary source was surfacewater inflow (southeast tributary and other nearshore areas), which contributed 23 percent of the total input. Most of the phosphorus from surface-water inflow enters in the southeast tributary. With the best approximations considered, septic systems were estimated to contribute about 16 percent of the phosphorus during the 1-year study period. With the worse-case assumptions considered, septic systems would contribute about 19 percent of the total input to the lake. Approximately 47 percent of the total phosphorus input to the lake $(206 \mathrm{lb})$ was exported through the outlet. The remaining 53 percent of the phosphorus input $(231 \mathrm{lb})$ was deposited in the bed sediment of the lake.

\section{Effects of Changes in Phosphorus Loading}

Most of the phosphorus entering Muskellunge Lake comes from natural sources (ground water flowing through undeveloped areas to the north of Muskellunge Lake); however, septic systems were estimated to contribute about 16 percent of the total input. One way to determine how this additional phosphorus from septic systems affects the water quality of the lake is through the use of empirical models. These models relate phosphorus loading to measures describing lake-water quality (such as phosphorus and chlorophyll $a$ concentrations and Secchi depth).

Empirical models contained in the Wisconsin Lake Modeling Suite (WiLMS, Panuska and Kreider, 2002) were used to assess how phosphorus input from septic systems affects the water quality of Muskellunge Lake. Of the 13 models contained in WiLMS, 9 were applicable to the hydrologic system of Muskellunge Lake (table 3). Therefore, the morphometry of the lake, the water and phosphorus loadings for the study period (November 2000 through October 2001), and the same hydrology with loading from septic systems removed were input into these models, and then phosphorus concentrations were simulated. Each of the models simulates an average phosphorus concentration for a specific season (table 3 ). The average phosphorus concentration simulated by the models for these different seasons with all phosphorus inputs included was $35 \mu \mathrm{g} / \mathrm{L}$,

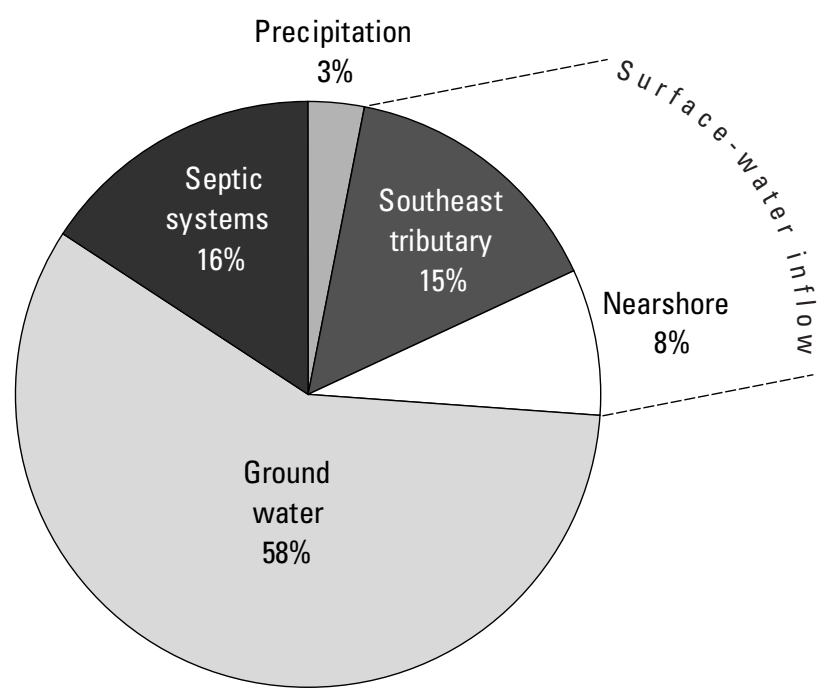

Figure 11. Phosphorus budget for Muskellunge Lake, Wisconsin, November 1, 2000 to October 31, 2001.

slightly lower than the average of the seasonally averaged data measured in the lake (about $43 \mu \mathrm{g} / \mathrm{L}$ ). The models were then applied with the phosphorus from the septic systems removed. Without input from septic systems, the average phosphorus concentration in the lake decreased by $4.4 \mu \mathrm{g} / \mathrm{L}$ (a reduction in concentration of 12.7 percent, table 3). If it were assumed that the models should be used only to predict the percentage of change in phosphorus rather than absolute concentrations, then if phosphorus from septic systems were removed, the average summer near-surface phosphorus concentration should decrease from the summer average during 2001 of $49 \mu \mathrm{g} / \mathrm{L}$ (fig. 5) to $43 \mu \mathrm{g} / \mathrm{L}$.

Empirical relations have also been developed that predict average summer chlorophyll $a$ concentrations and Secchi depths from near-surface phosphorus concentrations. Relations developed for Wisconsin lakes by Lillie and others (1993), also contained within WiLMS, were applied to determine how the changes in phosphorus concentration in the lake associated with the removal of septic system effluent should affect chlorophyll $a$ concentrations and Secchi depths. These models predicted that, with the measured average summer phosphorus concentration of $49 \mu \mathrm{g} / \mathrm{L}$, the lake should have a chlorophyll $a$ concentration of $13.5 \mu \mathrm{g} / \mathrm{L}$ (compared to $23 \mu \mathrm{g} / \mathrm{L}$ measured during 2001) and a Secchi depth of $4.3 \mathrm{ft}$ (compared to $3.6 \mathrm{ft}$ measured). The predicted average summer phosphorus concentration of $43 \mu \mathrm{g} / \mathrm{L}$ was then input into the relations. 
The models then predicted a chlorophyll $a$ concentration of $12.6 \mu \mathrm{g} / \mathrm{L}$ (a 7-percent reduction from $13.5 \mu \mathrm{g} / \mathrm{L}$ predicted for $49 \mu \mathrm{g} / \mathrm{L}$ of phosphorus) and a Secchi depth of $4.3 \mathrm{ft}$ (no change from that predicted for $49 \mu \mathrm{g} / \mathrm{L}$ of phosphorus). If it is again assumed that the models should be used only to predict the percentage of change, the removal of septic-system effluent should result in chlorophyll $a$ concentrations decreasing from the measured summer average of $23 \mu \mathrm{g} / \mathrm{L}$ to $21 \mu \mathrm{g} / \mathrm{L}$ and little change in the average summer Secchi depth.

Removal of septic-system effluent should improve water quality only slightly. Phosphorus concentrations in the lake should decrease by almost the same percentage as the decrease in phosphorus loading rates, whereas chlorophyll $a$ concentrations should decrease by a smaller percentage and Secchi depths should change very little. Similarly, phosphorus loading from septic-system effluent has probably slightly degraded the water quality of Muskellunge Lake. Because there are few other anthropogenic sources of phosphorus, the water quality simulated by the models when septic-system effluent is removed is what the water quality should have been prior to development in the area.
Bottom sediments of a lake represent a natural record of the lake's history and enable much to be inferred about historical changes in sediment and nutrient loading to the lake and water chemistry within the lake. Analyses of sediment cores extracted from Muskellunge Lake were used to describe the water quality of the lake more than 100 years ago (P. Garrison, Wisconsin Department of Natural Resources, written commun., 2000). Results from analysis of the diatom community from deep in the core (historical information) and near the sediment-water interface (recent information) indicated that historical nutrient levels in Muskellunge Lake were higher than those in many other lakes in the region and that the lake was already eutrophic more than 100 years ago. Changes in the diatom community indicate that phosphorus concentrations in the lake have increased very little over the last 100 years (less than $5 \mu \mathrm{g} / \mathrm{L}$ ); however, the changes in the diatoms also indicate that the macrophyte community has increased in density over this period.

The small changes in water quality inferred from changes in the diatom community in the sediment records agree with those found when comparing early water-quality data (collected in the 1970s) with recent data (2001).

Table 3. Estimated phosphorus concentrations, in micrograms per liter, in Muskellunge Lake from various phosphorus-loading models contained in the Wisconsin Lakes Modeling Suite (Panuska and Kreider, 2002)

\begin{tabular}{|c|c|c|c|c|}
\hline \multirow[b]{2}{*}{ Lake model } & \multicolumn{2}{|c|}{ Measured } & \multicolumn{2}{|c|}{ Modeled } \\
\hline & $\begin{array}{l}\text { Prediction } \\
\text { season }\end{array}$ & $\begin{array}{c}\text { Seasonal } \\
\text { concentration }\end{array}$ & $\begin{array}{l}\text { Phosphorus loading } \\
\text { of } 437 \text { pounds (with } \\
\text { septic-system effluent) }\end{array}$ & $\begin{array}{l}\text { Phosphorus loading } \\
\text { of } 368 \text { pounds (without } \\
\text { septic-system effluent) }\end{array}$ \\
\hline Walker, 1985 (Reservoirs) & Growing Season & 49 & 35 & 31 \\
\hline $\begin{array}{l}\text { Canfield and Bachman, } 1981 \\
\text { (Natural lakes) }\end{array}$ & Spring & 36 & 35 & 31 \\
\hline $\begin{array}{l}\text { Canfield and Bachman, } 1981 \\
\text { (Artificial lakes) }\end{array}$ & Spring & 36 & 30 & 26 \\
\hline Rechow, 1977 (Anoxic lakes) & Growing Season & 49 & 54 & 45 \\
\hline $\begin{array}{l}\text { Rechow, } 1977 \\
\text { (Water load < } 164 \text { feet/year) }\end{array}$ & Growing Season & 49 & 27 & 23 \\
\hline Walker, 1977 (General lakes) & Spring & 36 & 38 & 32 \\
\hline Vollenweider, 1982 (General lakes) & Annual & 43 & 28 & 25 \\
\hline Vollenweider, 1982 (Shallow lakes) & Annual & 43 & 23 & 20 \\
\hline Nurnberg, 1984 (Oxic lakes) & Annual & 43 & 46 & 43 \\
\hline Average concentration & & 43.4 & 35.1 & 30.7 \\
\hline Reduction, in micrograms per liter & & & & 4.4 \\
\hline Reduction, in percent & & & & 12.7 \\
\hline
\end{tabular}




\section{Summary}

Muskellunge Lake is a productive, eutrophic lake with an average summer total phosphorus concentration of 40 to $50 \mu \mathrm{g} / \mathrm{L}$, chlorophyll $a$ concentration of 10 to $30 \mu \mathrm{g} / \mathrm{L}$, and Secchi depth of about $4 \mathrm{ft}$. Historical data for each of these constituents indicate that water quality has degraded only slightly since the early 1970 s, possibly as a consequence of septic-system effluent discharged to the lake. On the basis of nitrogen-to-phosphorus ratios measured in the lake, the productivity in the lake is limited by the supply of phosphorus. A detailed phosphorus budget for the lake indicated that 58 percent of the phosphorus enters with ground water, 23 percent with surfacewater inflow, 16 percent from septic-system effluent, and 3 percent from direct precipitation. Most of this phosphorus appears to come from natural sources-ground water and surface water flowing through relatively undeveloped areas surrounding the lake. Modeling results indicated that the natural input of phosphorus was sufficient to maintain eutrophic conditions. An analysis of sediment cores confirms that nutrient and algal concentrations have changed only slightly over the past 100 years. The analysis of the cores indicated, however, that the macrophyte community has increased in density over this period. To alleviate winter anoxia (a common problem associated with shallow productive lakes) an aeration system was installed in Muskellunge Lake. This system functions as it was designed and maintains adequate dissolved oxygen concentrations (concentrations above $2 \mathrm{mg} / \mathrm{L}$ ) throughout the main body of the lake during winter.

\section{References}

Black, J.J., Andrews, L.M., and Threinen, C.W., 1963, Surface water resources of Vilas County: Madison, Wis., Wisconsin Conservation Department.

Canfield, D.E., and Bachmann, R.W., 1981, Prediction of total phosphorus concentrations, chlorophyll $a$, and Secchi depths in natural and artificial lakes:

Canadian Journal of Fisheries Aquatic Sciences, v. 38, p. 414-423.

Carlson, R.E., 1977, A trophic state index for lakes: Limnology and Oceanography, v. 22, p. 361-369.

Correll, D.L., 1998, The role of phosphorus in the eutrophication of receiving waters-A review: Journal of Environmental Quality, v. 27, p. 261-266.
Garn, H.S., Olson, D.L., Seidel, T.L., and Rose, W.J., 1996, Hydrology and water quality of Lauderdale Lakes, Walworth County, Wisconsin, 1993-94: U.S. Geological Survey Water-Resources Investigations Report 96-4235, $29 \mathrm{p}$.

Haitjema, H.M., 1995, Analytic element modeling of ground-water flow: San Diego, Calif., Academic Press, $394 \mathrm{p}$.

Hunt, R.J., Anderson, M.P., and Kelson, V.A., 1998, Improving a complex finite-difference ground water flow model through the use of an analytic element screening model: Ground Water, v. 36, no. 6., p. 1011-1017.

Lillesand, T., Chipman, J., Nagel, D., Reese, H., Bobo, M., and Goldman, R., 1998, Upper Midwest GAP analysis image processing protocol: Onalaska, Wis., U.S. Geological Survey, Environmental Management Technical Center, EMTC 98-G00, 25 p.

Lillie, R.A., Graham, Susan, and Rasmussen, Paul, 1993, Trophic state index equations and regional predictive equations for Wisconsin Lakes: Wisconsin Department of Natural Resources Management Findings, no. 35, 4 p.

Michigan Department of Natural Resources, 2002, Fish kills: accessed December 19, 2002 at URL http://www.michigan.gov/dnr/0,1607,7-153-10364_ 10951_18964-45765--,00.html

Nurnberg, G.K., 1984, The prediction of internal phosphorus load in lakes with anoxic hypolimnia: Limnology and Oceanography, v. 29, p. 111-124.

Panuska, J.C., and Kreider, J.C., 2002, Wisconsin lake modeling suite program documentation and user's manual, Version 3.3 for Windows: Wisconsin Department of Natural Resources PUBL-WR-363-94, 32 p. [Available online through the Wisconsin Lakes Partnership: accessed December 19, 2002 at URL http: //www.dnr.state.wi.us/org/water/fhp/lakes/laketool.htm]

Reckhow, K.H., 1977, Phosphorus models for lake management: Ph.D. dissertation, Harvard University, Cambridge, Massachusetts. Catalog No. 7731778, University Microfilms International, Ann Arbor, Michigan.

Reckhow, K.H., Beaulac, M.N., and Simpson, J.T., 1980, Modeling phosphorus loading in lake response under uncertainty-A manual and compilation of export coefficients: U.S. Environmental Protection Agency, EPA-440/5-80-011. 
Rose, W.J., 1993, Water and phosphorus budgets and trophic state, Balsam Lake, northwestern Wisconsin, 1987-89: U.S. Geological Survey Water-Resources Investigations Report 91-4125, 28 p.

Shaw, B., Mechenich, C., and Klessig, L., 1993, Understanding lake data: G3582: University of Wisconsin Extension, Madison, Wis., 19 p.

U.S. Geological Survey, Wisconsin District Lake-Studies Team, 2002, Water-quality and lake-stage data for Wisconsin lakes, water year 2001: U.S. Geological Survey Open-File Report 02-135, 149 p.

Vollenweider, R.A., and Kerekes, J. 1982, Eutrophication of waters-monitoring, assessment, and control: Paris, Organization for Economic Co-operation and Development (OECD), 156 p.

Walker, W.W., Jr., 1977, Some analytical methods applied to lake water quality problems: Ph.D. dissertation, Harvard University.

Walker, W.W., Jr., 1985, Empirical methods from predicting eutrophication in impoundments, report no. 3, Phase II- Model refinements: Vicksburg, Miss., U.S. Corps of Engineers Waterways Experimental Station Technical Report no. E-81-9, 300 p.
Waschbusch, R.J., Olson, D.L., Ellefson, B.R., and Stark, P.A., 2002, Water-resources data Wisconsin, water year 2001: U.S. Geological Survey Water-Data Report WI-01-1, $610 \mathrm{p}$.

Wentz, D.A., and Rose, W.J., 1991, Hydrology of Lakes Clara and Vandercook in north-central Wisconsin: U.S. Geological Survey Water-Resources Investigations Report 89-4204, 24 p.

Wisconsin Department of Natural Resources, 1985, Little St. Germain, Vilas County, feasibility study results and management alternatives: Bureau of Water Resources Management, Lake Management Program, 22 p.

Wisconsin Department of Natural Resources, 2002, Selfhelp citizen lake monitoring: accessed September 25, 2002 at URL http://www.dnr.state.wi.us/org/water/fhp/ lakes/shlmmain.shtml

Wisconsin State Laboratory of Hygiene, Environmental Sciences Section, 1993, Manual of analytical methods, inorganic chemistry unit: Wisconsin State Laboratory of Hygiene, revised November 1993 [variously paged]. 
